\title{
Pelatihan Pemanfaatan Spreadsheet untuk Meningkatkan Kompetensi Guru SMK Bisnis dan Manajemen dalam Menyusun Laporan Keuangan
}

\author{
Spreadsheet Utilization Training to Improve the Competence of Business and Management \\ Vocational School Teachers in Compiling Financial Reports
}

Nayang Helmayunita ${ }^{*}$
Ade Elsa Betavia ${ }^{1}$
Dovi Septiari ${ }^{1}$
Sany Dwita ${ }^{2}$
1Department of Accounting,
Universitas Negeri Padang, Padang,
West Sumatra, Indonesia
2Department of
Universitas Negeri Padang, Padang,
West Sumatra, Indonesia
email: nayang.helma@gmail.com
Kata Kunci
Microsoft Excel
Pelatihan
Spreadsheet
Keywords:
Microsoft Excel
Training
Spreadsheet
Published: April 2021

\begin{abstract}
Abstrak
Berdasarkan wawancara yang dilakukan dengan Ketua Musyawaran Guru Mata Pelajaran Sekolah Menengah Kejuruan Bisnis dan Manajemen di Propinsi Sumatera Barat, ditemukan bahwa guru perlu meningkatkan kompetensinya berhubungan dengan penggunaan Aplikasi Komputer Akuntansi. Diketahui bahwa masih kurangnya kompetensi yang dimiliki oleh guru, dan masih kurang familiarnya guru dengan cara mengoperasikan berbagai macam menu dan fungsi yang dapat digunakan dalam program spreadsheet untuk menyelesaikan laporan keuangan perusahaan. Berdasarkan kondisi ini, maka selama ini proses belajar mengajar untuk mata pelajaran lebih banyak dilakukan dengan metode ceramah dan sedikit praktik. Sehingga hal ini berpengaruh terhadap kompetensi para lulusan SMK. Padahal, tuntunan dunia kerja mensyaratkan para lulusan SMK harus bisa mengoperasikan program aplikasi ini dengan baik. Kegiatan kepada masyarakat ini dilakukan selama dua hari pada tanggal 18 dan 19 September 2020 di SMKN 2 Kota Padang. Pelaksanaan dilakukan melalui tiga tahapan, yaitu pemaparan materi, latihan terpadu, dan evaluasi. Pada akhir kegiatan diketahui bahwa terdapat peningkatan pemahaman dari peserta mengenai penyusunan laporan keuangan perusahaan dagang dengan menggunakan Microsoft Excel dengan tingkat nilai penyelesaian kasus yang dapat dicapai adalah $85,71 \%$. Selanjutnya peningkatan kompetensi guru ini diharapkan dapat ditransfer ke siswa dan tercermin dari nilai UKK dan penerimaan lulusan di dunia kerja.
\end{abstract}

\begin{abstract}
Based on interviews conducted with the Head of the Vocational High School Management and Business Vocational High School Subject Teacher Conference in West Sumatra Province, it was found that teachers need to improve their competence about the use of Computer Accounting Applications. It is known that teachers still lack competence, and teachers are still unfamiliar with how to operate various menus and functions that can be used in a spreadsheet program to complete company financial reports. Based on this condition, the teaching and learning process for subjects has been done more with the lecture method and a little practice. So that this affects the competence of SMK graduates. In fact, the guidance for the world of work requires SMK graduates to operate this application program properly. The community's activity was carried out for two days on 18 and 19 September 2020 at SMKN 2 Kota Padang. The implementation is carried out in three stages, namely material presentation, integrated training, and evaluation. At the end of the activity, it was known that there was an increase in the understanding of the participants regarding the preparation of financial statements of trading companies using Microsoft Excel with a case settlement value that could be achieved was $85.71 \%$. Furthermore, this increase in teacher competence is expected to be transferred to students and is reflected in the value of UKK and the acceptance of graduates in the world of work.
\end{abstract}




\section{PENDAHULUAN}

Perkembangan kemajuan suatu bangsa salah satu indikatornya adalah semakin majunya sektor pendidikan. Melalui sektor pendidikan yang maju, sumber daya manuasia yang terampil dan terdidik akan dapat mendorong pertumbuhan ekonomi suatu negara. Selain sebagai pendorong pertumbuhan ekonomi, sektor pendidikan tentu saja juga menjadi faktor utama pendorong pembangunan. Adanya peningkatan penguasaan ilmu dan teknologi merupakan bukti nyata dari keberhasilan pembangunan (Widiansyah, 2017; Rasyid, 2015).

Kemajuan ilmu pengetahuan dan teknologi ini tidak lepas dari keberhasilan proses pembalajaran yang ada di institusi pendidikan dan lembaga pendidikan. Sekolah dan perguruan tinggi merupakan salah satu institusi pendidikan yang memiliki peranan penting untuk meningkatkan pengetahuan dan keterampilan tersebut. Pengetahuan dan keterampilan yang diberikan pada sekolah-sekolah akan menjadi dasar bagi lulusan sekolah tersebut untuk dapat terjun dalam dunia kerja. Sehingga tuntutan adanya pengetahuan dan keterampilan merupakan hal yang mutlak yang harus ada bagi para lulusan (Falah, 2015; Efferi, 2013).

Perkembangan teknologi juga merubah proses bisnis perusahaan menjadi terkomputerisasi. Telah banyak perusahaan-perusahaan yang bahkan masih berskala kecil dan menengah yang mensyaratkan pekerjanya untuk mampu menguasai penggunaan komputer. Hal yang paling umum bagi perusahaan-perusahaan tersebut dalam penggunaan komputer adalah dalam hal penyusunan laporan keuangan dengan menggunakan program Microsoft Excel. Hal ini menjadi bukti bahwa dunia kerja membutuhkan tenaga kerja yang siap pakai yang harus memiliki keahlian yang dibutuhkan oleh dunia kerja (Kuswanto, 2013; Utami, 2010).
Sekolah Menengah Kejuruan merupakan salah satu alternatif institusi pendidikan yang menjawab tantangan perkembangan zaman yang menuntut adanya tenaga kerja yang siap pakai diusia yang relatif muda. Sehingga keberadaan Sekolah Menengah Kejuruan dirasakan penting oleh pemerintah. Untuk itu, dibentuklah Direktorat Pembinaan Menengah Kejuruan untuk menyediakan SDM yang berkualitas yang dibutuhkan sesuai dengan perkembangan zaman (Malikah, 2014).

Peningkatan Teknologi juga berdampak pada perkembangan program akuntansi. Program penyusunan laporan keuangan dengan menggunakan progam Microsoft Excel merupakan salah satu program yang dibutuhkan oleh dunia kerja atau perusahaan, baik perusahaan besar maupun UMKM. Untuk itu, SMK hendaknya menjawab tantangan zaman dengan mengenalkan program ini sebagai keahlian tambahan bagi siswanya (Helmayunita et al., 2019).

Mata pelajaran spreadsheet atau paket program pengolah angka merupakan mata pelajaran produktif akuntansi kompetensi keahlian akuntansi di SMK Bisnis dan Manajemen, sehingga, mata pelajaran ini sangatlah kompleks dan harus disampaikan kepada siswa. Kompetensi yang diharapkan pada mata pelajaran ini adalah siswa mampu dalam mengoperasikan paket program pengolah angka/spreadsheet yang dapat membuat pembelajaran sebagai pembentukan kepribadian diri bagi siswa akuntansi (Ginayanti, 2016). Musyawarah Guru Mata Pelajaran (MGMP) adalah sarana peningkatan pengetahuan bagi guru mata pelajaran tertentu dengan komunitasnya. MGMP menjadi tempat meningkatkan dan memperbaharui pengetahuan, diskusi, dan membantu guru dan komunitasnya dalam memecahkan masalah yang terkait dengan bidang ilmunya (Hasyim, 2015). Berdasarkan hasil diskusi pengusul dengan ketua MGMPSMK Bisnis dan Manajemen di Provinsi Sumatera Barat, ditemukan 
bahwa guru perlu meningkatkan kompetensinya berhubungan dengan penggunaan Aplikasi Komputer Akuntansi. Berdasarkan UU Dikdasmen No. 130/D/Kep/2017, aplikasi pengolah angka dan Microsoft Excel merupakan keahlian yang wajib dimiliki siswa SMK Bisnis dan Manajemen.

Pelatihan mengenai program komputer akuntansi dipandang perlu bagi guru-guru SMK Bisnis dan Manajemen di Provinsi Sumatera Barat. Para guru akuntansi SMK bisnis dan Manejemen ini merasakan masih banyak kendala yang mereka hadapi dalam menyelesaikan siklus akuntansi menggunakan program spreadsheet. Berdasarkan wawancara yang dilakukan dengan Ketua MGMP Provinsi Sumatera Barat, diketahui bahwa hal ini terjadi karena masih kurangnya kompetensi yang dimiliki oleh guru, dan masih kurang familiarnya guru dengan cara mengoperasikan berbagai macam menu dan fungsi yang dapat digunakan dalam program spreadsheet untuk menyelesaikan suatu laporan keuangan perusahaan. Berdasarkan kondisi ini, maka selama ini proses belajar mengajar untuk mata pelajaran ini lebih banyak dilakukan dengan metode ceramah dan sedikit praktik. Sehingga hal ini berpengaruh terhadap kompetensi para lulusan SMK. Padahal tuntunan dunia kerja, mensyaratkan para lulusan SMK harus bisa mengoperasikan program aplikasi ini dengan baik.

Tuntutan dunia kerja yang mensyaratkan tenaga kerja yang mampu untuk menyusun laporan keuangan dengan program microsoft menjadi faktor penting yang perlu diperhatikan guru. Tuntutan dari dunia kerja tersebut menyebabkan guru harus lebih ekstra mempersiapkan calon lulusannya. Untuk dapat mempersiapkan calon lulusan yang mampu bersaing dalam dunia kerja, maka guru-guru harus memiliki pengetahuan terkait dengan perkembangan teknologi penyusunan laporan keuangan. Sehingga pengetahuan yang dimiliki oleh guru-guru terebut dapat diberikan dengan baik kepada siswanya (Mungkasa, 2020).

Guru menjadi faktor penting dalam meningkatkan kualitas tenaga kerja yang dihasilkan sekolah menengah kejuruan (Kementerian Pendidikan dan Kebudayaan Republik Indonesia, 2015). Universitas sebagai bentuk pendidikan tinggi ikut berperan meningkatkan kompetensi guru secara berkelanjutan melalui pengabdian masyarakat. Pelatihan ini ditujukan untuk guru MGMP SMK Bisnis Provinsi Sumatera Barat. Adapun program akuntansi yang akan dilatih yaitu: penyusunan laporan keuangan perusahaan dagang dan manufaktur dengan menggunakan program Microsoft Excel. Diharapkan dengan pelatihan ini, kompetensi guru terhadap program komputer akutansi meningkat; sehingga berhubungan langsung dengan peningkatan kompetensi siswa yang tercermin dari nilai UKK dan terserapnya lulusan di dunia kerja.

Berdasarkan analisis situasi yang telah dilakukan, maka dapat dirumuskan masalah dalam kegiatan ini yaitu:

1. Berkembangnya teknologi yang berdampak pada perkembangan program komputer akuntansi

2. Masih minimnya pengetahuan guru SMK Bisnis dan Manajemen terhadap perkembangan program komputer akuntansi

3. Perlunya program pelatihan yang dapat meningkatkan pengetahuan dan keterampilan guru SMK dalam menggunakan beberapa program komputer akuntansi

Berdasarkan hasil wawancara dan observasi dengan tim guru-guru MGMP Akuntansi SMK Bisnis dan Manajemen, ditemukan bahwa guru SMK Bisnis dan Manajemen Provinsi Sumatera Barat membutuhkan pelatihan tambahan untuk meningkatkan kompetensi terkait dengan program komputer akuntansi. Guru perlu meningkatkan kompetensi untuk membantu meningkatkan kompetensi siswa mereka agar lebih siap 
untuk terjun kedalam dunia kerja pada saat telah lulus nantinya. Selain itu mata pelajaran spreadsheet atau paket program pengolah angka merupakan mata pelajaran produktif akuntansi kompetensi keahlian akuntansi di SMK Bisnis dan Manajemen, sehingga mata pelajaran ini sangatlah kompleks dan harus disampaikan kepada siswa. UU Dikdasmen No. 130/D/Kep/2017 juga menyatakan bahwa aplikasi pengolah angka dan Microsoft Excel merupakan keahlian yang wajib dimiliki siswa SMK Bisnis dan Manajemen, sehingga guru juga perlu memperbarui pengetahuannya terhadap perkembangan program komputer akuntansi, salah satunya program penyusunan laporan keuangan dengan menggunakan Microsoft Excel.

Permasalahan yang dihadapi di lapangan, salah satunya yaitu guru belum mengetahui sepenuhnya mengenai fungsi program Microsoft Excel yang dapat digunakan sebagai sarana untuk menyusun laporan keuangan sederhana perusahaan. Banyaknya penggunaan teknolgi dalam menyelesaikan siklus akuntansi, mengharuskan siswa mengenal dan fasih mnggunakan program di komputer akuntansi. Dengan meningkatnya kompetensi guru, diharapkan guru dapat mentransfer keahliannya kepada siswa. Guru adalah jendela yang membuka pengetahuan. Jika guru tidak memiliki kemampuan, maka transfer pengetahuan dan keahlian kepada siswa pun menjadi tidak maksimal (Ogearti, 2020).

Pelatihan program komputer akuntansi bagi guru SMK Bisnis dan Manajemen diharapkan dapat memberikan pengetahuan dan keahlian bagi guru. Pengetahuan berarti guru akan mengenal fungsi dan menu dalam program ini dan keahlian berarti guru terbiasa dan tidak "kagok" lagi menggunakan program ini. Guru pun dapat bertanya kepada narasumber mengenai ketidapahaman mereka mengenai penyusunan laporan keuangan sederhana suatu perusahaan.
Pelatihan ini direncanakan akan diadakan dalam tiga hari. Pelatihan ini tidak hanya memberikan pengetahuan bagi guru mengenai program computer akuntansi, tapi lebih memfokuskan pada praktik sehingga guru dapat langsung mempraktikkan materi yang diberikan oleh narasumber. Dengan praktik secara langsung diharapkan guru memahami program ini dan jika ada kendala maka dapat bertanya kepada narasumber. Melalui pelatihan ini diharapkan guru MGMP SMK jurusan Bisnis dan Manajemen Provinsi Sumatera Barat mendapatkan pengetahuan dan keahlian tentang program komputer akuntansi dalam menyelesaikan siklus akuntansi.

\section{METODOLOGI}

Metode yang digunakan dalam kegiatan ini adalah memberikan pelatihan melalui bimbingan terpadu kepada guru MGMP SMK jurusan Bisnis dan Manajemen dengan langkah-langkah sebagai berikut:

1. Metode ceramah dan diskusi

Metode ini digunakan untuk menyampaikan pengetahuan oleh narasumber mengenai jenis-jenis laporan keuangan pada perusahaan. Selain itu juga dijelaskan mengenai menu dan siklus penyusunan laporan keuangan dengan menggunakan program excel for accounting. Peserta pelatihan dapat bertanya mengenai hal-hal yang belum dipahami dalam program ini kepada marasumber.

2. Demonstrasi

Metode ini merupakan metode untuk mempraktikan pengetahuan yang telah didapat. Guru SMK mempraktikkan menggunakan program komputer akuntansi dengan dipandu oleh narasumber. Kegiatan tersebut dapat dilaksanakan melalui tahapan berikut:

a. Persiapan: menghubungi koordinator tim MGMP ekonomi SMK jurusan Bisnis dan 
Manajemen Provinsi Sumatera Barat untuk menyepakati jadwal dan lokasi kegiatan.

b. Kegiatan inti: Pada pertemuan yang telah disepakati diberikan pelatihan selama dua hari.

c. Monitoring: dimaksudkan untuk melihat sejauh mana kemampuan peserta dalam memahami materi yang telah disampaikan.

Pada kegiatan ini, dilakukan monitoring dan evaluasi terhadap keberhasilan pembinaan yang telah dilakukan. Untuk mengetahui tingkat ketercapaian tujuan, maka evaluasi dilakukan sebanyak tiga kali, yaitu awal, proses dan akhir. Lembar evaluasi awal dilakukan untuk mengetahui kemampuan guru dalam menggunakan prorgam komputer akuntansi sebelum diberikan pelatihan. Lembar evaluasi akhir dilakukan untuk mengetahui kemampuan guru dalam menggunakan program ini setelah pelatihan diberikan. Lembar evaluasi proses bertujuan untuk melihat keaktifan dan rasa ingin tahu peserta terhadap materi pelatihan yang diberikan. Evaluasi proses dilakukan dengan mengisi ceklist yang dilakukan oleh anggota tim kegiatan pengabdian.

\section{HASIL DAN PEMBAHASAN}

Kegiatan PKM "Pelatihan Pemanfaatan Spreadsheet untuk Meningkatkan Kompetensi Guru SMK Bisnis dan Manajemen dalam Menyusun Laporan Keuangan" dilakukan melalui beberapa tahapan, yaitu:

\section{Tahapan Persiapan}

Tahapan persiapan pada kegiatan ini dilakukan dimulai dari melakukan koordinasi dengan ketua MGMP Akuntansi Provinsi Sumatera Barat terkait dengan waktu pelaksanaan. Koordinasi ini dilakukan satu bulan sebelum pelaksanaan. Hal ini perlu dilakukan untuk menyesuaikan jadwal antara tim pelaksana, pemateri dan peserta pelatihan. Setelah didapatkan waktu yang disepakati, tim pelaksana mengajukan surat kepada LP2M terkait dengan surat izin pelaksanaan kegiatan pengabdian. Surat ini ditujukan kepada ketua MGMP Akuntansi Provinsi Sumatera Barat dan Kepala SMKN. 2 Padang selaku mitra yang bekerja sama dalam pelaksanaan kegiatan ini. Setelah surat izin ini dikeluarkan, surat tersebut diberikan kepada ketua MGMP Akuntansi Provinsi Sumatera Barat untuk dilanjutkan kepada anggota MGMP Akuntansi Provinsi Sumatera Barat.

Tim pelaksana selanjutnya menyusun rundown kegiatan pelatihan, dan menunjuk pemateri yang berkompeten untuk sebagai pembicara pada pelatihan ini. Selain itu tim pelaksana juga mengajukan permintaan penerbitan surat tugas kepada LP2M untuk tim dan pemateri kegiatan.

Dua minggu sebelum kegiatan, MGMP Akuntansi Provinsi Sumatera Barat telah memberikan nama peserta pelatihan kepada pelaksana untuk dibuatkan draft absensi kegiatan. Jumlah peserta awal yang ditargetkan hanya berjumlah 20 orang, ternyata melebihi yang direncanakan. Peserta yang mendaftar berjumlah sebanyak 35 orang. Hal ini menunjukkan tingginya keinginan dari para guru Akuntansi anggota MGMP untuk mengikuti pelatihan ini. Selain itu sebelum pelaksanaan pelatihan, tim pelaksana juga menyiapkan seminar kit, spanduk, dan penggandaan bahan materi untuk para peserta pelatihan.

\section{Tahapan Pelaksanaan}

Kegiatan PKM "Pelatihan Pemanfaatan Spreadsheet untuk Meningkatkan Kompetensi Guru SMK Bisnis dan Manajemen dalam Menyusun Laporan Keuangan" ini telah dilaksanakan pada tanggal 18 dan 19 September 2020 bertempat di SMKN. 2 Padang. Jumlah peserta yang mengikuti pelatihan ini adalah sebanyak 35 orang. 
Pelaksanaan kegiatan PKM ini dilaksanakan dalam kondisi pandemik yang sedang terjadi. Sehingga untuk pelaksanaan, maka tim pelaksana dan pihak MGMP membuat serangkaian protokol kesehatan adaptasi kebiasaan baru untuk pencegahan COVID 19. Protokol kesehatan ini merujuk kepada protokol kesehatan yang dianjurkan oleh pemerintah. Serangkaian protokol kesehatan tersebut antara lain:

a. Perorangan:

1) Selalu menggunakan masker

2) Mencuci tangan dengan sabun dan air mengalir setiap saat

3) Membawa dan menggunakan hand sanitizer

4) Hindari menyentuh wajah

5) Menerapkan etika batuk dan bersin

6) Selalu jaga jarak (physical distancing)

7) Bagi peserta yang merasakan kurang sehat, diminta untuk tidak hadir atau izin pulang

8) Tidak berjabat tangan, cukup mengucapkan salam dalam menyapa peserta lain dan tamu undangan.

9) Menggunakan fasilitas kursi meja yang sama (tidak berpindah tempat) selama kegiatan

10) Selalu menjaga kebersihan

b. Penyelenggara Kegiatan (UNP dan Pengurus MGMP)

1) Menyediakan tempat cuci tangan dengan sabun serta air mengalir

2) Menyemprot ruangan dengan disinfektan sehari sebelum ruangan digunakan

3) Pengaturan jarak kursi/meja minimal 1,5 meter

4) Menghindari penggunaan AC/Kipas Angin

5) Menyediakan tempat sampah

Pada pelaksanaan hari pertama, dimulai dari jam 07.30 registrasi ulang peserta dilakukan, setiap peserta yang akan mengikuti kegiatan ini diminta untuk mencuci tangan terlebih dahulu, kemudian dilakukan pengukuran suhu. Bagi peserta yang memiliki suhu badan diatas $38^{\circ} \mathrm{C}$, tidak diizinkan untuk mengikuti kegiatan ini dan diminta untuk pulang. Setiap peserta diwajibkan untuk memakai masker yang telah disediakan oleh tim pelaksana. Tepat jam 08.00, dilakukan pembukaan kegiatan pelatihan yang dibuka secara langsung oleh Ketua MGMP Ekonomi dan Bisnis Provinsi Sumatera Barat yaitu Ibu Ernawaty, S.Pd. Setelah itu dilakukan pretest untuk mengetahui sejauhmana pengetahuan dasar para peserta pelatihan terkait dengan penyusunan laporan keuangan perusahaan dagang dengan menggunakan spreadsheet.

Materi pertama diberikan oleh Nayang Helmayunita, SE, M.Sc terkait dengan Pengenalan fitur-fitur Microsoft Excel untuk penyusunan laporan keuangan. Setelah itu dilanjutkan dengan materi Praktikum Membuat Jurnal Khusus yang dipandu oleh Ade Elsa Betavia, SE, M.Sc, materi selanjutnya adalah membuat dan mengisi buku besar yang dipandu oleh Charoline Cheisviyanny SE, AK, M.AK dan Vanica Serly, SE, M.Si.

Pada hari kedua, dilanjutkan dengan pemberian materi terkait dengan penyusunan neraca saldo dan jurnal penyesuaian yang dipandu oleh Herlina Helmy, SE, Ak, M.S.Ak selanjutnya materi membuat neraca lajur dipandu oleh Deviani, SE, Ak, M.Si. materi terakhir yaitu penyusunan laporan keuangan dipandu oleh Dr. Efrizal Syofyan, SE, Ak, M.Si, CA. Kondisi pandemik sekarang menyebabkan kegiatan pelatihan hanya dapat dilakukan selama 2 hari secara tatap muka. Untuk hari ketiga dan keempat dilakukan secara daring, untuk hari ketiga dilakukan latihan terpadu menyusun laporan keuangan perusahaan jasa dengan menggunakan Microsoft Excel latihan ini dimoderatori oleh Dovi Septiari SE, 
M.Sc. selanjutnya pada hari keempat dilakukan ujian terpadu untuk menyusun laporan keuangan perusahaan dagang. Ujian ini dipandu oleh Sany Dwita, SE, Ak, M.Si, Ph,D.

\section{Tahapan Evaluasi}

Untuk mengevaluasi kegiatan PKM ini, maka dilakukan evaluasi dalam 2 bentuk. Evaluasi yang pertama dilakukan dalam bentuk pemberian soal pretest yang dilakukan sebelum pelatihan dimulai. Pretest ini dilakukan untuk mengetahui sejauhmana pengetahuan dasar dari peserta pelatihan sebelum dilakukan pemberian materi. Setelah itu pada hari terakhir sebelum dilakukan penutupan kegiatan, dilakukan evaluasi posttest. Ini dilakukan untuk melihat pencapaian yang diperoleh oleh peserta pelatihan setalah mereka mendapatkan materi. Tabel I menggambarkan pencapaian skor yang dapat diperoleh oleh peserta pelatihan sebelum dan setelah melaksanakan pelatihan:

\begin{tabular}{|c|c|c|c|}
\hline No. & Keterangan & Pretest & Posttest \\
\hline 1. & $\begin{array}{l}\text { Pencatatan transaksi } \\
\text { kedalam jurnal }\end{array}$ & 35 & 35 \\
\hline 2. & Pengisian buku besar & 27 & 35 \\
\hline 3. & $\begin{array}{l}\text { Penyusunan neraca } \\
\text { saldo }\end{array}$ & 24 & 35 \\
\hline 4. & $\begin{array}{l}\text { Pencatatan jurnal } \\
\text { penyesuain }\end{array}$ & 18 & 35 \\
\hline 5. & Pengisian neraca lajur & 13 & 33 \\
\hline \multirow[t]{2}{*}{6.} & $\begin{array}{l}\text { Penyusunan laporan } \\
\text { keuangan }\end{array}$ & 8 & 30 \\
\hline & Persentase pencapaian & $22,85 \%$ & $85,71 \%$ \\
\hline
\end{tabular}

Berdasarkan pada hasil tabel diatas, diketahui bahwa terdapat peningkatan pemahaman peserta setelah mengikuti pelatihan ini. Pada pelaksanaan pretest, penyelesaian soal pretest hanya sebesar 22,85\%, sedangkan setelah dilakukan pelatihan tingkat penyelesaian laporan keuangan perusahaan dagang adalah 85,71\%. Hasil ini menunjukkan bahwa pelatihan yang diikuti oleh peserta telah memberikan peningkatan penambahan pemahaman bagi peserta pelatihan.
Selain evaluasi terkait pemahaman peserta, evaluasi juga dilakukan terkait dengan proses pelaksanaan pelatihan. Evaluasi ini dilakukan melaui kuesioner yang diberikan kepada peserta. Pada kuesioner ini pelaksana meminta saran dan kritik terkait dengan pelaksanaan kegiatan PKM ini. Berdasarkan hasil yang diperoleh, didapatkan bahwa peserta meminta untuk dilakukan kembali pelatihan yang dapat berjalan secara berkesinambungan terkait dengan penyusunan laporan keuangan untuk manufaktur dengan menggunakan program Microsoft Excel.

\section{KESIMPULAN}

Berdasarkan pada pelaksanaan pelatihan PKM "Pelatihan Pemanfaatan Spreadsheet untuk Meningkatkan Kompetensi Guru SMK Bisnis dan Manajemen dalam Menyusun Laporan Keuangan” ini, dapat diketahui bahwa melalui pelatihan ini pemahaman dan kompetensi guru SMK Akuntansi dapat meningkat. Hal ini dapat dilihat dari pencapaian nilai posttest yang mengalami peningkatan yang signifikan dari nilai prestestnya. Para peserta pelatihan dapat melaksanakan tugas komprehensif ini dengan baik. Hal ini memberikan bukti bahwa pelatihan yang dilakukan ini dapat memberikan peranan yang sangat penting dalam meningkatkan kompetensi guru SMK Bisnis dan manajemen terutama guru akuntansi dalam mengajar mata pelajaran komputer akuntansi.

\section{UCAPAN TERIMA KASIH}

Terima kasih kami ucapkan kepada pihak-pihak yang telah membantu terlaksananya kegiatan pengabdian ini, kepada Bapak Prof. Dr. Yasri, MS, selaku Ketua LP2M UNP dan Ibu Ernawaty S.Pd, selaku Ketua MGMPSMK Ekonomi dan Bisnis Provinsi Sumatera Barat. 


\section{REFERENSI}

Efferi, A. 2013. Peran PTAI dan Peningkatan Mutu Tenaga Pendidik. Quality. 1(2):86-112. http://dx.doi.org/10.21043/quality.v1i2.216

Falah, A. 2015. Studi Analisis Aspek-Aspek Keberhasilan Pembelajaran Pendidikan Agama Islam Di Sdn 01 Karangmalang Gebog Kudus. Elementary: Islamic Teacher Journal. 3(1):171-195. http://dx.doi.org/10.21043/elementary.v3i1. 1449

Ginayanti, N.S. 2016. Peningkatan Hasil Belajar Operasional Spreadsheet Jenis dan Fungsi dengan Rumus Statistik Akuntansi melalui Demonstrasi dan Presentasi. Jurnal Ilmiah Econosains. 14(2):177-184. https://doi.org/10.21009/econosains.0142.07

Hasyim, M. 2015. Efektifitas Musyawarah Guru Mata Pelajaran (MGMP) Guru Pendidikan Agama Islam. Jurnal Pusaka: Media Kajian dan Pemikiran Islam. 2(2):30-43.

Helmayunita, N., Serly, V., Honesty, H.N. 2019. PKM Peningkatan Kompetensi Guru SMK Dalam Bidang Komputer Akuntansi. Wahana Riset Akuntansi. 7(2):1521-1528. https://doi.org/10.24036/wra.v7i2.106935

Kementerian Pendidikan dan Kebudayaan Republik Indonesia. 2015. Rencana Strategis Direktorat Pembinaan SMK (PSMK) Tahun 2015-2019. Jakarta: Kementerian Pendidikan dan Kebudayaan Republik Indonesia.

Kuswanto, H. 2013. Dampak Perubahan Lingkungan Bisnis Terhadap Perusahaan, Organisasi, Manajemen Strategi Dan Akuntansi Manajemen. Dharma Ekonomi. 20(37):1-14.

Malikah, N. 2014. Pragmatisasi Pendidikan dalam Dunia Kerja. Nadwa: Jurnal Pendidikan Islam. 8(1):155170. https://doi.org/10.21580/nw.2014.8.1.575

Mungkasa, O. 2020. Bekerja dari Rumah (Working from Home/WFH): Menuju Tatanan Baru Era Pandemi COVID 19. Jurnal Perencanaan Pembangunan: The Indonesian Journal of Development Planning. $\quad 4(2): 126-150$. https://doi.org/10.36574/jpp.v4i2

Ogearti, R. 2020. Identifikasi Kendala Dalam Pemanfaatan Microsoft Excel Untuk
Pembuatan Laporan Keuangan. Jurnal Akuntansi Profesi. 11(2):339-350. http://dx.doi.org/10.23887/jap.v11i2.30688

Rasyid, H. 2015. Membangun Generasi Melalui Pendidikan Sebagai Investasi Masa Depan. Jurnal Pendidikan Anak. 4(1):565-581. https://doi.org/10.21831/jpa.v4i1.12345

Utami, S.S. 2010. Pengaruh Teknologi Informasi Dalam Perkembangan Bisnis. Jurnal Akuntansi dan Sistem Teknologi Informasi. 8(1):61-67.

Widiansyah, A. 2017. Peran Ekonomi dalam Pendidikan dan Pendidikan dalam Pembangunan Ekonomi. Cakrawala: Jurnal Humaniora Bina Sarana Informatika. 17(2):207-215. https://doi.org/10.31294/jc.v17i2.2612 